\title{
EDUCATE FOR TECHNOLOGICAL INNOVATION
}

\author{
Smulders, Frido; Broekhans, Bertien; Kamp, Aldert; Hellendoorn, Hans; Welleman, Hans \\ Delft University of Technology
}

\begin{abstract}
At Polytechnics design \& engineering students are taught about state-of-the-art technical knowledge. Students become qualified engineers and learn to innovate artifacts related to their domain.

Not taught is how to develop new engineering knowledge within a multidisciplinary context of stakeholders, companies and regulations. In short, students don't learn to innovate technology. What is taught today is the result of a technological innovation of yesterday. This is not sufficient for industry to innovatively deal with society's grand challenges.

The paper describes a project that aims to educate all TU Delft graduate students in the verb of innovating technology, that is, the development of new technologies from inventions in the labs to fullfledged application in business. Such along three dimensions: technical, human and business.

The educational portfolio consists of three modules in line with growth along Bloom's taxonomy and online materials on theoretical backbones. All modules apply the notion of technological innovation journeys (Tijo's). Tijo's are rich descriptions of the developmental journey of new technology and are based on inventions from the university's own labs.
\end{abstract}

Keywords: Education, Technology, Innovation, Entrepreneurship, Human behaviour technology

\section{Contact:}

Smulders, Frido

Delft University of Technology

Industrial Design Engineering

The Netherlands

f.e.h.m.smulders@tudelft.nl

Cite this article: Smulders, F., Broekhans, B., Kamp, A., Hellendoorn, H., Welleman, H. (2019) 'Educate for

Technological Innovation', in Proceedings of the 22nd International Conference on Engineering Design (ICED19), Delft,

The Netherlands, 5-8 August 2019. DOI:10.1017/dsi.2019.52 


\section{INTRODUCTION}

Present engineering education inattentions one important element: the verb of how to innovate technology. The project described in this paper aims to fill this void by developing in co-creational fashion, various educational modules for this new avenue in engineering education.

Society is facing grand challenges on energy transition, global warming, over population, etc. To deal with these challenges, companies hiring engineers increasingly look for people trained to innovate, who are able to contribute to the desirability (society level), viability (business level) and operability (human level) of new technical ideas that can address these challenges (O'Kleefe \& Rottenberg, 2017). Therefore, there is a need for engineers who are able to cross boundaries and integrate human and business dimensions along the technical dimension. Engineering education must focus on teaching beyond the technical dimension of 'the innovation' and broaden the spectrum to innovate in multidisciplinary settings (Kamp, 2014; Smulders et al., 2018). This entails not just teaching the maturity of technology along a technical dimension, but ensuring that the human and business dimensions are also coherently integrated (Figure 1).

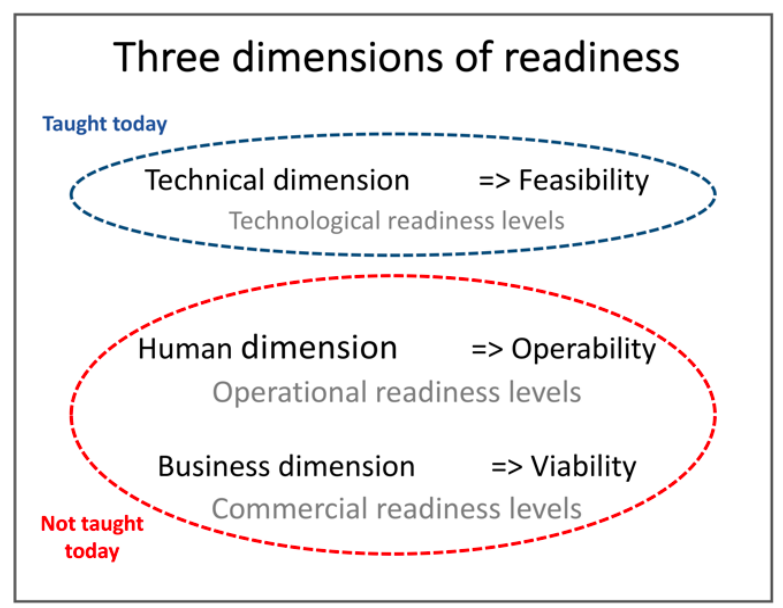

Figure 1: Maturing readiness along three dimensions: technical, human \& business.

Engineering education at MSc-level is presently constituted by teaching existing and to a large extent domain specific and validated technological knowledge to create valuable engineers for the respective domains. Students are trained in these specific bodies of 'technology', hence, aerospace, civiltechnology, marine-technology, etc. with a focus on the feasibility of technical design. They are taught how to apply existing technological knowledge to relevant design and engineering challenges within their domain. The dominant focus of engineering programs, at least in The Netherlands, over the last half a century or so, was to increase the levels of specialisation in order to address the societal needs in that period. However, the challenges in the world have changed, engineering knowledge is to be found everywhere, engineers frequently change jobs and move even to other domains. Consequence of all this is that only a very limited amount of engineers stays within their specialised track of education and specialise even further. The majority moves out of their specialisation and a considerable number even out of their domain to other related or distant domains. Is this a problem? Not really, we still need lots of engineering specialists and the fundamental knowledge they received related to the physical sciences is universally applicable and therefor evenly relevant to be applied in other domains. However, seen from an abstracted business perspective, all engineers are participating in and contributing to innovation processes. They always work on something new that needs to be introduced in an existing situation. Be it parts, bridges, dikes, ships, electronics, sensors, etc. ... and this is exactly how innovation is defined. What engineering students at the four Dutch technical universities (4TU) learn about innovation is domain related. They learn about the new technologies, the new applications and the new insights and how to apply these to in-domain engineering challenges. Apart from the fact that this leaves out the human and business dimensions it also neglects two other topics: 1) the potential application of existing technologies to different classes of objects in new domains. And 2), the capricious processes of maturing technology from invention in the (university) labs till full-fledged readiness in industrial practice. 
And there is a strong need to do so. Not just because of the societal challenges, but evenly because most of technical accidents are not just technical and find their root causes in human failures. The countless disasters around the implementation of ICT-programs have not just technical causes, but find their roots in complex interrelations between the technical and the human. Think of the recent case of Boeing's 737 MAX. First it is the pilots that made mistakes, but then it seems to turn into a (innovation) management failure by Boeing and the pilots are nothing to blame (Hatchuel, 2019). Management not being capable enough to handle the complexity and interrelatedness of the three dimensions while engaged in technological innovating. The observation raises the question of who educated these managers and engineers? Yes, we as academics are responsible for that. If business schools educate managers and universities of technology raises engineers, who then is responsible for educating the technological innovators? We believe, universities of technology should take the lead and feel supported by recent strategic incentives to adapt Delft's MSc-programs for educating "responsible engineers of tomorrow".

So what is our challenge? In fact, there are two challenges. The first is to develop courseware that addresses these voids, or better, addresses these opportunities. The second is related to the existing situation of highly specialized 2 year MSc-programs. These programs are fully loaded and aim to deliver students the most advanced and specialized content of the field. A situation that is in conflict with the idea of replacing specialist content with generic and 'modern' topics, like innovation and entrepreneurship. However, as educational innovators we still think there are opportunities to address this societal need and find ways to overcome these hindrances. It is our aim develop a program that reaches out to all $35 \mathrm{MSc}$-degrees and teach all MSc-students, 3000 and growing, some of the basics of the verb of technological innovating as briefly addressed above.

This paper describes the program we have in mind and illustrates by some cases what we see as the content that needs to be covered in course modules. The remainder of the paper is structured as follows. First, we will describe some developments in engineering education to position our project of innovating engineering education. This is followed by two cases that are illustrative for the relevance of teaching technological innovation from the perspective of the three dimensions: technical, human and business.

The same section will end by providing our ideas and first steps that aim to create a generic and integrated framework representing the processual perspective of the verb of technological innovation. Section 4 discusses the development of knowledge for practice seen through the lens of the engineering sciences to end up with drawing a parallel with the knowledge needed to arrive at fullfledged business operations that encompass the new technology. In section 5 we will present the basic ideas of the educational modules that we believe will be capable of addressing our main challenge: how to reach all MSc-students of TU Delft in an already fully filled curriculum. In addition two other courses will complete the learning line. The final section of this paper briefly addresses our aim to build university wide community as the second ingredient for success.

\section{ENGINEERING EDUCATION: SOME DEVELOPMENTS}

The present engineering education is dominantly aimed at teaching students what is necessary to become 'engineers that can engineer' in the daily practice of organizations. Building a tight connection between engineering education and engineering practice complementary to traditional teaching, is a main aim of the CDIO initiative (more than 100 universities of technology world-wide) (Crawley et al., 2011). The CDIO-framework, well-known among engineering educators, stands for conceive-design-implementoperate as the sequence that objects under development need to go through (e.g. Malmqvist, 2017). This framework for engineering education advocates frequent design-build cycles including a strong focus on teamwork and interpersonal skills in addition to the deep technical knowledge belonging to the various disciplines. The CDIO-framework is therefore believed to provide a holistic perspective on engineering education that mimics the engineering profession. A profession that by default forms a crucial partner in technological innovation processes. Although the CDIO-framework advocates teamwork and interdisciplinary skills, it lacks a theoretical base that will help us to educate for interdisciplinarity, hence the human dimension. It also lacks the business dimension and its theoretical underpinnings. Furthermore, it aims to bring existing technological knowledge into practice instead of focusing on the development of new engineering knowledge and/or the transfer and transforming of existing technologies for application in other domains (Smulders et al., 2018). 
According to the vision of a think tank at Delft University it was found that engineering education needs to move from content coverage to content mastery and educate what was referred to as the 'whole engineer' (Kamp, 2015; Kamp \& Klaassen, 2016). Meaning, instead of filling the brains of our students with more and more technological content and specialized knowledge, it is better to provide them with the skills to master the process of content development, in fact, teach our students to become capable leaders of technological innovation processes. In addition, and in resonance with what the CDIO network advocates, future engineers will need to have interdisciplinary skills and understand the process that brings complex products and systems to life in a collaborative setting of many involved disciplines, hence the human dimension (Kamp, 2015). Such is often referred as $21^{\text {st }}$ century skills. Which is in line with what Roth (2014) mentions to move towards liberal education and what Robinson and Aronica mention about getting creativity back into education. From our perspective these observations and suggestions show some overlap with Delft's aim to educate 'responsible engineers of tomorrow'.

In this paper we aim to go one step further and will include the human \& organizational dimension as well as the business dimension. In short, for becoming responsible engineers our students will need to have an understanding of how technical feasibility intertwines with human operability and business viability during the maturing process. And as the case of Boeing's 737 illustrates, the responsibility goes beyond the technology to invade the management practices.

Throughout the world there are many initiatives that address parts of what is mentioned above. Some of these programs are executive programs (LEAD at Stanford, Innovation programs at Harvard) and others offer courses open to graduate and undergraduate students. For instance, some courses on engineering innovation stress the importance of paying attention to (product) innovation and illustrate what innovation could mean for engineers by showing the strategic business relevance. There are full-fledged multi-year undergraduate and graduate programs like in Eindhoven, Netherlands. In short, world-wide there are courses, programs and universities that have similar content on offer. However, what we didn't found (yet) is to provide learning modules based on one generic and integrated framework to all graduate/MScengineering students of the university.

\section{TECHNOLOGICAL INNOVATING: TWO ILLUSTRATIVE CASES}

This section will deepen the two variations of technological innovating mentioned: the transfer of a technology to a new domain and the development of a new technology within an existing domain. Figure 2 shows what we teach to engineering students today (blue) and what we aim to add with our educational innovation project (yellow). It also positions the two examples (in red) that will be discussed below.

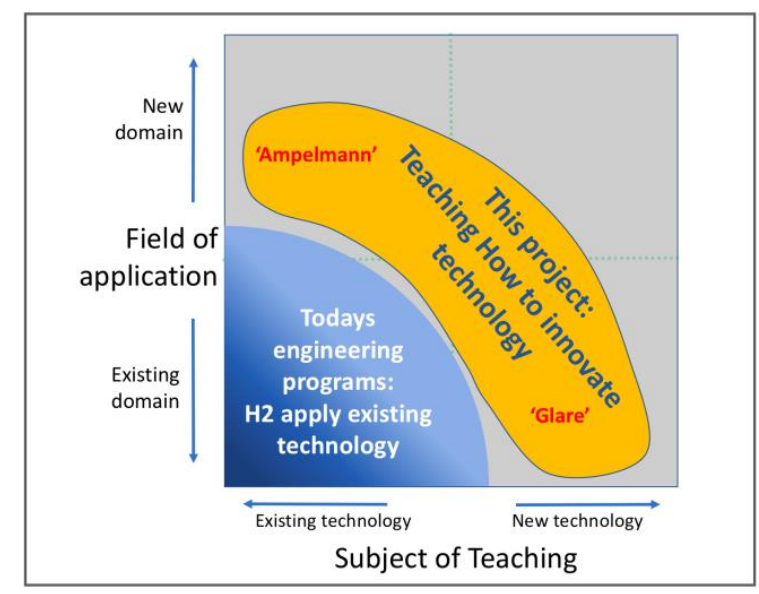

Figure 2: What is presently taught in engineering programs and what is the aim of the project: how to innovate technology.

These topics are not taught and certainly not at the experiential level. An illustrative example for each of these two topics to clarify this omission.

\subsection{The innovative transfer of an existing technology to a new domain.}

The technology of a Stewart Platform (Stewart, 1965), or a 6 DoF Platform (Degrees of Freedom), was originally developed for testing tires and later moved to become the dominant technology for flight 
simulators. On an offshore wind conference some bride and creative $\mathrm{PhD}$-students learned about the troublesome transfer of maintenance people from moving ships to seabed based (static) wind turbines. Over a beer or two they got the idea to apply the technology of a Stewart-platform for this problem. Their creative leap was to flip the technology around by compensating movements in 6 directions instead of creating movements in these 6 directions, hence 6 DoF. So, instead of having a non-moving ground base and the Stewart Platform introducing movements to the flight simulator they flipped this around. The movements of the ship in 6 directions would be compensated by the Stewart Platform to create a nonmoving connection and safe transfer to the wind turbine. In order to innovate this technology into a fullfledged business the young guys started their own new venture: Ampelmann (ampelmann.nl). Based on scientific research (Cerda Salzmann, 2010) they were able to move from scale models (2005) and prototypes (2006) to their first commercial project in 2008. In between the company was founded and grew to a successful business with 8 offices worldwide and over 5 milj. safe people transfers from moving ships to static seabed based platforms and turbines. The engineering entrepreneurs learned how to innovate a technology from idea in the lab to successful application in business and therefore focused on all three dimensions (tech, human, business) to ensure its success. They also learned that their original idea of selling their Ampelmann platforms to customers didn't work and that they had to alter their business model into offering service contracts in which Ampelmann employees would operate and maintain the platforms on the ships of their customers. Such a late changeover of business model could have jeopardized the whole project. However, in this case they were able to handle the consequential extra efforts to recruit, train and create a worldwide network of offices.

The educational message here is that we should teach engineering students the basics of tech based venturing along the three dimensions: human, business \& technical. What are success factors and what factors could hamper the transfer of existing technologies to new domains. We need to teach the integrated technological innovation process in such a way that our students are capable of frontloading downstream considerations related to the three dimensions (Thomke \& Fujimoto, 2000).

\subsection{The development of new technology within its domain}

The case concerns the development of a new class of structural materials for airplanes within TU Delft. The development of ARALL (Aramid (= Kevlar) Reinforced Aluminium Laminate) in the early 80's and GLARE (Glass Reinforced Aluminium Laminate) starting in the late 80's until its application in the fuselage of Airbus A380, beginning of this century (Vlot, 2001). These two materials form the first sets belonging to new class and combine the properties of aluminium with those from composites and by that dramatically increase fatigue resistance of metal sheets. After discovery of ARALL and the early positive test results it was decided to develop the material and prepare it for the market through a certification program. The positive results in coherence with the development of feasible production methods led to promising contacts with aircraft manufacturers and material suppliers. At that moment the core solution principle of aramid fibres and thin aluminium sheets got frozen which made investments by industry the logical next step. One of them, Alcoa, acquired a licence to introduce ARALL to the market and invested heavily into setting up a new operational chain. Shortly after these initial successes in the mid-eighties problematic issues started to surface: fibre failure and fatigue cracks under loading conditions of a fuselage, one of the most promising application areas. It was an indication that either test methods were not adequate, or the core solution of the material concept itself. It proved to be both! The 'surprise' initiated a series of research projects that had to uncover the mechanism of fibre failure. Ultimately and by the extensive use of microscopic investigations the complex fibre failure mechanism was uncovered and validated (Smulders, 1988). In parallel there were some early applications. One of these, cargo door of a military air lifter, looked promising at first. But after the first series of doors it was realized that from economic perspective applying ARALL was not the right solution at all. The manufacturing of the panels turned out to be far too labour intensive and costly to make up for its advantages in weight, inspection and maintenance savings. On the other hand, the insights created by describing the fibre failure mechanism challenged some fundamental assumptions regarding the core principle of the fibre material. At the outset, it was assumed that applying the lightest suitable fibres (aramid) would be most advantageous to safe weight. The microscopic research uncovering the mechanism revealed that this choice had to be considered sub-optimal (Smulders 1988; Roebroeks, 1991) and seen from a viability standpoint not a good choice at all. The material designers identified glass fibres, although somewhat heavier than aramid, to best fulfil the new requirements. The result was GLARE, the second generation of fibre metal laminates. 
The deeper theoretical understanding of the fibre metal laminate culminated in a much more focused GLARE Technology Development program incorporating a different attitude and approach by the researchers and developers (Gunnink et al., 2002). It included adaptations of design and, manufacturing methods and a review of maintenance approaches to assure business viability: It was for instance discovered that conventional maintenance and repair methods that were based on metal proved to be adequate. Such prevented aircraft operators to spend scarce resources on the development and validation of entirely new maintenance methods and by that an easier transition from the labs to the industry. However, the development process of this new material was not all smooth. From first ideas till first applications it took 30 years and the involvement of many industrial partners that moved in and out due to misunderstandings, disagreements alternating strategic decisions and the iteration around its core solution (Van Burg et al., 2014). The dynamics of such a technological innovation process in which not just the technology, but evenly the human and business dimensions play key roles should become part of the curriculum of engineering students.

The key educational message here is pretty much similar as with the first case, however, understanding the key role of the university as provider of the new body of engineering knowledge could support engineers in practice as well as researchers in the lab with additional capabilities that aim to jump the famous 'valley of death' that is believed to exist between science and industry (Markham, 2002; Markham et al., 2010). Knowing how to frontload market and business considerations and make these part of the scientific cycle might facilitate the university-industry transfer.

\subsection{First steps towards a theoretical framework}

Let's start with a working definition of the verb of innovating. Based on the Latin 'innovare', -bring in something new- we define innovating as 'changing an existing situation by the introduction of something new' (Smulders, 2015). The newness here is based on the amount of changes and their deviation from the 'ist'-situation that were needed to cover the full trajectory till use of the new in existing situation/context/environment. Consider for instance the development and market introduction of a new model vacuum cleaner versus the development and delivery to its first customer of Boeing's Dreamliner. Incremental innovations could be defined as new products that apply existing and proven technology. Radical innovations make use of new technologies, cutting edge technologies that just past the threshold of applicability, reliability and safety (Garcia \& Calantone, 2002). And also arrived at an acceptable maturity level along the three dimensions mentioned: technical, human and business. For the purpose of this paper, we define technology as ways of working that allow the users of the technology to design, engineer, manufacture, operate and/or maintain new artefacts in a predictable manner. Predictability of technical behaviour is a condition-sine-qua-non for engineers. For companies, predictability not just concerns the technical behaviour of the artefact, but also the predictability of new ways of working as a whole. If these don't deliver predictable results in operability, viability and/or feasibility, the technology is not ready for a scaling. Note that with our requirement of predictability for all three dimensions we move beyond the traditional descriptions of technology readiness to integrate readiness of all three dimensions into one.

The two examples in the last section are illustrative for the kind of knowledge that should become part of future engineering education. The theory on technological innovation, however, is not uniform, nor describing the integrated process of maturing covering technical, human and business dimensions as an integrated whole (Malmqvist, 2012). A substantial amount of literature focuses on the newness of the technology in relation to adoption variables by industrial actors and their markets (e.g. Garcia \& Calantone, 2002). Such often takes the newness of the end product from a marketing \& consumer perspective into account, which is at the very back-end of innovating and partly beyond the focus of our project. For our purpose, we will include theories and concepts from a large variety of fields to arrive at understandable, relevant and teachable theoretical framework. Here we will provide a peek into the streams of literature that we consider relevant which is illustrative for the complexity of our challenge. We will need to digest, integrate and turn these streams of literature into one framework. Key requirement for the framework is its practicality for teaching and application by our future engineers. This is all about action learning and therefore we quote social psychologist Kurt Lewin: "There is nothing so practical as a good theory."

For the purpose of the length of this paper we will only refer to a selection of literature streams and key authors. The inception part of new technological opportunities could of course start with serendipity, but equally with (designer's) creativity. Literature on serious creativity, creative facilitation and design theory 
(e.g. Rittel \& Webber, 1973; Schön, 1983; Dorst \& Cross, 2001; Hatchuel \& Weil, 2009) will be of value not just at the start, but creativity is essential throughout the full length of the process. The literature on technological innovating is important like the literature on how to bridge the gap between science and industry, overcoming the so-called Valley of Death (e.g. Markham, 2002; Smulders, 2017). Literature on innovation processes (e.g. Buijs, 2003 \& 2012) and within established organizations (e.g. Van de Ven, 1986, Van de Ven et al., 1999; Smulders, 2006) and literature around startups (e.g. Keskin, 2015), new ventures (e.g. Ries, 2011; Müller \& Thoring, 2012) and entrepreneurship education (e.g. Nielsen \& Gartner, 2017; Van Oorschot, 2018). Inter- and cross-disciplinary communication (e.g. Smulders et al., 2008; Smulders \& Bakker, 2012) Business modelling (e.g Osterwalder et al., 2005; Muegge, 2012). Organizational behaviour which in its turn is to be considered as interdisciplinary combination of sociology, organizational psychology and economics. Technological marketing and high tech product introductions (e.g. Chiesa \& Frattini, 2011; Huarng et al., 2015). Socio-interactive processes and innovative behaviour (e.g. Lorino, 2018; Smulders \& Dunne, 2016). The considerable amount of self- citations of the first author is to be seen as indicative for some in-depth knowledge regarding the here proposed trajectory to develop the required framework.

\section{TRAJECTORY TOWARDS NEW (ENGINEERING) KNOWLEDGE}

From the above cases and descriptions of our aim with this project of teaching the verb of innovating technology, one could conclude that all activities by all actors involved aim to develop new and additional knowledge. From that standpoint it is interesting to have a look how engineering knowledge develops and gets embedded in daily practices and routines. In a simplified manner one could say that most engineering curricula teach: how to design and engineer products related to a certain disciplinary class of artefacts (bridges, dikes, ships, planes, etc.). Engineers in practice bear huge responsibility to make sure all what they develop is $100 \%$ reliable for its purpose. Dikes shouldn't break, bridges shouldn't collapse, planes shouldn't crash. And much more. In order for engineers to trust what they have learned at the polytechnic school, universities perform fundamental research that in generic sense follows the sequence as depicted in Figure 3.

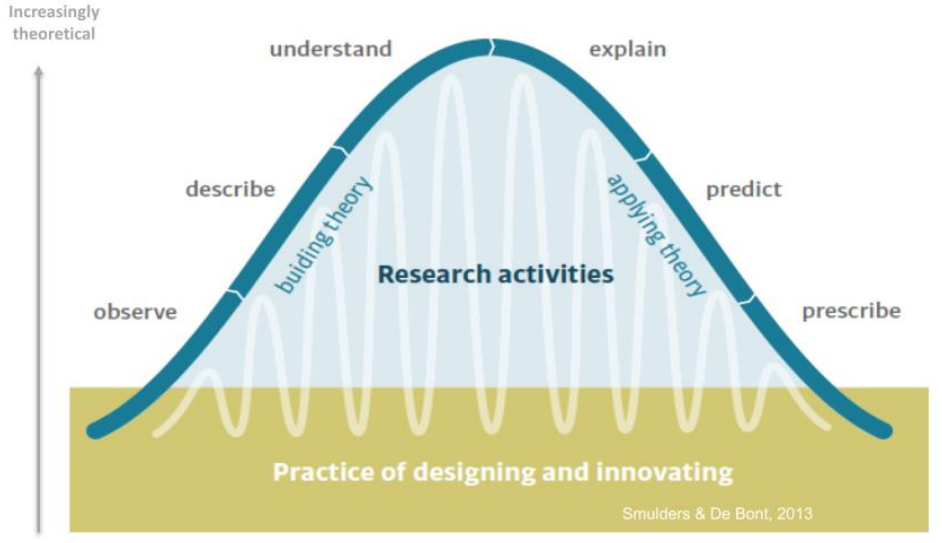

Figure 3: Schematic representation of the empirical trajectory of science (Smulders \& De Bont, 2013)

Let's have a look at what scientific research within the engineering sciences actually aims to achieve. Scientific researchers, as discussed by De Groot (1994), Dorst (2008) and others, embark on activities that, roughly, follow the sequence: observe, describe, understand, explain, predict and prescribe, hence validated engineering knowledge (Smulders \& De Bont, 2013).

Figure 3 provides a schematic overview of this sequence starting from natural or artificial behaviour (Simon, 1996) within the empirical world at the bottom of the graph to gradually move to higher levels of theoretical understandings and explanations. The essence is to build new (or additional) theory in a grounded manner (Glaser \& Strauss, 1967) by inductively, abductively and iteratively moving or 'climbing' into the theoretical realm to arrive at an integrated theoretical representation of the substantive field under study. Along the way researchers use existing theoretical notions as scaffolds for their inductive path and searching new fledgling notions that act as footholds or as 'climbing pitons'. Moving from empirical observations via understanding these observations towards an explanatory vocabulary integrating existing and new notions into a testable whole of hypotheses (e.g. Smulders, 1988 \& 2006). Experimental 
settings will support or falsify these hypotheses and will require iterations backwards to the formulated theory and/or forward to validation of the new engineering knowledge and to ultimately end up as prescriptions of its use. Et voila, new engineering knowledge is born. Finally, there are prescriptive texts, that add to the existing body of engineering knowledge, that is, prescriptive engineering handbooks. What is taught today is typically the existing and validated engineering knowledge and not the process that leads to new and validated engineering knowledge as is hinted to earlier in this paper.

However, it is the innovator's intention to develop an integrated body of knowledge that becomes the new practice and routines of which the technical dimension is just one third. Since, we have a similar challenge regarding setting up a framework that represents the processual perspective of technological innovation, we have to blend the social sciences with the physical sciences, business (economics) and human dimensions on one side and technical on the other side. In the Figure 3, we could place the social sciences on the upper left side with understanding and some explanations of human and business behaviours, but by far no predictive behaviour. Such will place extra pressure on our future teaching. Engineering students typically are trained to here formula's, validated theories and proven ways of working. Teaching ambiguous (soft) theories and frameworks to this class of students forms an extra challenge. In extreme, there are no truths in the social sciences, only probabilities. This requires two different mind sets in order to capture and have some understanding of the verb of technological innovating. The next section will address our main challenge: how to bring students some understanding of this real-life complexity without diluting existing engineering programs?

\section{TOWARDS EDUCATIONAL MODULES AND DIDACTICS}

We aim to develop four educational modules to be able to reach out to all $3000+$ graduate students of Delft University and to provide a longer learning line for a selection of students. Two of these address our main challenge: small in-course modules $(1-2 \mathrm{ec})$ in coherence with an online module that brings the envisioned theoretical framework. The third aims to educate our professors in how to blend their engineering teaching with leading Socratic discussions around the envisioned 'soft' and ambiguous framework.

Both for faculty commitment and connection to a wide range of courses and programmes, it seems essential to ground the new avenue of teaching in narratives about technology innovation close to our own faculty labs. The idea is to develop technological innovation journeys, Tijo's, based on inventions from TU Delft's own labs. These inventions from the past, once reached applicative maturity along the three dimensions, typically are part of the present teaching by our professors. In each of the separate MSc-programs we aim to seek such inventions as base for the Tijo's. Once the Tijo's are ready, the professor teaching that specific part of engineering knowledge, will embed some Tijo based interactive sessions in his/her course in a format of Case Based Learning (CBL). The students will analyse these Tijo' using the theoretical framework on technological innovation supplied in an online module. This way and over time we aim to address all MSc-students of Delft.

Tijo's report on the full development trajectory from its first ideas and patents in our university labs to the full-fledged application in industry, that is, the diffusion from inventor to a scaled set of users in industry. In short, all three dimensions will be addressed as one integrated storyline reporting on the journey and in tight connection to critical episodes. These critical (unexpected) episodes are important to allow students to build their personal framework of understanding that explains the why of: hurdles \& pitfalls, failures \& mistakes, successes \& coincidences, perplexed \& serendipitous insights, fights \& perceptions, unwanted \& deliberate iterations, test series \& prototypes, frictions \& setbacks, breakthroughs \& clueless, support \& resistances, etc. The essence of developing new technologies and put these to action in business settings, is to create new logics and truths that to some extent exchanges earlier logics and truths. Especially deep rooted assumptions \& beliefs that need to be challenged might take a long time and cause not-foreseen iterations, like the choice for aramid fibres in ARALL. Contrasting old logics \& assumptions with the new logics that eventually formed the building blocks of the new technology, business model and operational processes are essential opportunities for teaching the verb of technological innovation. It is the aim to extract a variety of 'mis'-somethings, like mistakes, misconceptions, misapprehensions, and misinterpretations and relate these to explanatory literature as found in our framework.

The Tijo's will be converted into cases ready for Case Based Learning (CBL). The Tijo's will provide the students with an imaginable real life situation that could be seen as a form of concrete experience. Individual and in-class reflections on these cases will promote understanding and subsequent internalizing of the associated theoretical framework (Kolb, 1984). Especially, the in-class discussions in the form of 
Fishbowl sessions will deepen students understanding of the theoretical framework as found in an online module (Smulders, 2011). The idea is to create a seamless fit of the Tijo's and the courses that teach the mature technology of the Tijo and by that bring our engineering students some basic understanding of the verb of technological innovation.

For developing the Tijo's we have the idea for a dedicated university wide MSc-elective (5ec) in which a minority of MSc-students (20-40) are coached while they create the Tijo's for the in-course modules. Tijo's will be domain specific and the participating teacher will act as a client for the development of the Tijo, since he/she is most knowledgeable and in need of the Tijo for his/her classes.

The third course, an advanced elective of 6ec, brings real-time technological innovation inside the classroom. The real-time innovation journey (e.g. at TU Delft's incubator YES!Delft) will provide the student's experiential base, or living lab. Aim is to address the methodology of technological innovation processes at deeper theoretical levels and ask students to act as technological innovation consultants and compose an advice to the technological innovators.

The final module concerns training the professors in teaching with Tijo's and by means of Fishbowl sessions. Engineering professors similarly have no background knowledge on the non-linearity, ambiguity and irrationality of the three dimensions belonging to technological innovation, nor on how to teach around these topics from that have their base in the social sciences.

\section{BUILDING UNIVERSITY-WIDE NETWORK}

In order to be successful we will build a university-wide community consisting of representatives from four levels: university board, educational directors, professors/researchers and students. The authors of this paper represent the directors and teachers level and represent four (out of seven) faculties. A good start that shows willingness to participate and embark on this co-creation project. The aim across the community is to share vocabulary and build discourse; to recruit new staff and students to join; to find courses to add on; to advocate objectives and bring educational materials; and to keep everybody on the same page. It is the aim to gradually grow the community of MSc-teachers until most of the MScprogrammes and tracks are included. An ambitious goal to be reached in 5 years.

\section{REFERENCES}

Buijs, J. (2003), "Modelling product innovation processes, from linear logic to circular chaos". Creativity and Innovation Management, Vol. 12 No. 2, pp. 76-93.

Buijs, J. (2012), The delft innovation method. The Hague: Eleven International Publishing.

Cerda Salzmann, D.J. (2010), Ampelmann. Development of access system for offshore wind turbines. (PhD thesis). Delft: Delft University of Technology.

Chiesa, V. and Frattini, F. (2011), “Commercializing Technological Innovation: Learning from Failures in High-Tech Markets”. Journal of Product Innovation Management, Vol. 28, pp. 437-454.

Crawley, E.F., Malmqvist, J., Lucas, W.A. and Brodeur, D.R. (2011), "The CDIO Syllabus v2.0. An updated statement of goals for engineering education". Proceedings of the 7th International CDIO Conference, Technical University of Denmark, Copenhagen.

De Groot, A.D. (1994), Methodologie. Grondslagen van onderzoek en denken in de gedragswetenschappen. Van Gorcum, Assen.

Dorst, K., and Cross, N. (2001), "Creativity in the design process: Co-evolution of problem-solution”. Design Studies, Vol. 22 No. 5, pp. 425-437.

Dorst, K. (2008), “Design research: A revolution-waiting-to-behappen”. Design Studies, Vol. 29 No. 1, pp. 4-11.

Garcia, R. and Calantone, R. (2002), "A critical look at technological innovation typology and innovativeness terminology: a literature review”. Journal of Product Innovation Management, Vol. 19, pp. 110-132.

Glaser, B.G. and Strauss, A.L. (1967), The discovery of grounded theory. Chicago: Aldine.

Gunnink, J.W., Vlot, A., De Vries, T.J., and Van der Hoeven, W. (2002), “Glare technology development 1997-2000”, Applied Composite Materials, Vol. 9, pp. 201-219.

Hatchuel, A. (2019), “737 MAX: als een ontwerpfout een managementfout lijkt geworden”. NRC, 28/03/2019. In French: Boeing 737 MAX : le spectre de l'erreur de conception., Le Monde, 27/03/19

Hatchuel, A. and Weil, B (2009), "C-K design theory: An advanced formulation”, Research in Engineering Design, Vol. 19, pp. 181-192.

Huarng, K-H, Yu, Hui-Kuang Yu, T., Wenhsiang, L. (2015), "Innovation and diffusion of high-tech products, services, and systems". Journal of Business Research, Vol. 68, pp. 2223-2226.

Kamp, A. (2014), Engineering Education in a Rapidly Changing World. Rethinking the Mission and Vision on Engineering Education at TU Delft. Delft University of Technology. 
Kamp, A. and Klaassen, R. (2016), "Impact of global forces and empowering situations on engineering education in 2030". Proceedings of the 12th International CDIO Conference, Turku University of Applied Sciences, Turku, Finland, June.

Keskin, D. (2015), Product Innovation in Sustainability-Oriented New Ventures. (PhD Thesis), Delft University of Technology.

Kolb, D.A. (1984), Experiential learning. Englewood Cliffs (NJ): Prentice-Hall.

Lorino, P. (2018), Pragmatism and organization studies. Oxford (GB): Oxford University Press.

Markham, S. (2002), "Moving technologies from lab to market”. Research-Technology Management, Vol. 45 No. 6 , pp. 31-42.

Markham, S.K., Ward, S.J, Aiman-Smith, L. and Kington, A. I. (2010), “The Valley of Death as Context for Role Theory in Product Innovation”. Journal of Product Innovation Management, Vol. 27, pp. 402-17.

Muegge, S. (2012)," Business Model Discovery by Technology Entrepreneurs." Technology Innovation Management Review, April, pp. 5-16.

Müller, R. M. and Thoring, K. (2012), "Design thinking vs. lean startup: A comparison of two user-driven innovation strategies". Leading Through Design, p. 151.

Nielsen, S. L. and Gartner, W. B. (2017), “Am I a student and/or entrepreneur?” Multiple identities in student entrepreneurship. Education + Training, Vol. 59 No. 2, pp. 135-154.

O'Keefe, A. and Rottenberg, S. (2017), "Integrated Design Innovation: A Mindset for Designers of Tomorrow". Design Management Review, Vol. 28 No. 3, pp. 10-16.

Osterwalder, A., Pigneur, Y. and C.L. Tucci (2005), "Clarifying Business Models: Origins, Present, and Future of the Concept”. Communications of the Association for Information Systems, Vol. 16, pp. 1-40.

Ries, E. (2011), The lean startup: How today's entrepreneurs use continuous innovation to create radically successful businesses: Crown Business.

Rittel, H. and Webber, M. (1973), "Dilemmas in general theory of planning”, Policy Sciences, Vol. 4, pp. 155-169.

Robinson, K. and Aronica, L. (2016), Creative Schools. The grassroots revolution that's transforming education”. Penguin Books, New York.

Roebroeks, G. (1991), Towards Glare. The development of a fatigue insensitive and damage tolerant aircraft material. $\mathrm{PhD}$ thesis, Delft, Delft University of Technology.

Roozenburg, N. F. and Eekels, J. (1995), Product design: fundamentals and methods, Wiley, Chichester.

Roth, M.S. (2014), Beyond the university. Why liberal education matters. Yale University Press, New Haven.

Schön, D.A. (1983), The reflective practitioner. New York: Basic Books.

Simon, H.A. (1996), The sciences of the artificial, MIT Press Ltd, Cambridge Mass, USA.

Smulders, F. (1988), Fibre fracture mechanism in Aral laminates with aramid fibres. TU Delft, MSc-thesis.

Smulders, F. (2006), Get synchronized! Bridging the Gap between Design \& Volume Production. (PhD thesis). Delft: Delft University of Technology.

Smulders, F. (2011), "Get wet! Teaching innovation theories through experiential learning". Journal of Design Research, Vol. 9 No. 2, pp. 168-184.

Smulders, F. (2017), "Heterogeneous engineering: Essential bridge implementing creative design". International Conference on Engineering Design (ICED). University of British Columbia, Vancouver, pp. 539-548.

Smulders, F.E., Lousberg, L. and Dorst, K (2008), “Towards different communication in collaborative design", International Journal of Managing Projects in Business, Vol. 1 No. 3, p. 352-367.

Smulders, F. and de Bont, C. (2012), "Design research: purpose, dynamics and progress" In C. de Bont, P. den Ouden, H. Schifferstein, F. Smulders and M. v.d. Voort (Eds.), Advanced Design Methods (pp. 213-237)

Smulders, F. and Bakker, H. (2012), "Modeling the inter-subjective level of innovation". Int. Journal of Technology Management, Vol. 60 No. 3/4, p. 221-241.

Smulders, F. and Dunne, D. (2016), "Disciplina: A Missing Link for Cross Disciplinary Integration". 11th Design Thinking Research Symposium, Copenhagen Business School, November 2016, Copenhagen, Denmark.

Smulders, F., Kamp, A. and Fortin, C. (2018), "The CDIO framework and new perspectives on technological innovation". Proceedings of the 14th International CDIO Conference, Kanazawa Institute of Technology Kanazawa (Japan), June 28 - July 2, p. 40-52.

Stewart, D. (1965), "A Platform with Six Degrees of Freedom”. Proceedings of the Institution of Mechanical Engineers. Vol. 180 No. 1, No. 15, p. 371-386. 10.1243/pime_proc_1965_180_029_02

Thomke, S. and Fujimoto, T. (2000), "The effect of "Front-Loading” on product development performance". Journal of Product Innovation Management, Vol. 17 No. 2, p. 128-142.

Van Burg, E., Berends, H. and van Raaij, E. (2014)," Framing and interorganizational knowledge transfer: A process study of collaborative innovation in the aircraft industry Journal of Management Studies”, Vol. 51 No. 3, p. 349-378.

Van de Ven, A.H., Polley, D.E., Garud, R. and Venkataraman, S. (1999), The innovation journey. Oxford University Press New York.

Vlot, A. (2001), Glare. History of the development of a new aircraft material. Kluwer Academic Publishers. 